\title{
Selected Online US Government Resources for Security Studies
}

\author{
Charmaine Henriques
}

\section{Purpose}

The aim of this work is to identify, promote and describe notable government information sources of research importance to students, faculty, scholars, and librarians in the field of Security Studies.

\section{Design/methodology/approach}

This paper gives an overview of no fee, publicly accessible US government databases, websites and electronic continuing publications related to Security Studies and produced by federal agencies or entities benefitting from government funding.

\section{Findings}

Information is provided about each resource, detailing search strategies and the variety of available content.

\section{Originality/value}

While there are a number of exceptional Security Studies bibliographies, they mostly focus on print materials, International Documents, and titles published by private/trade publishers. Furthermore, when US federal documents are mentioned, it is usually a specific government report or electronic monograph.

\section{Introduction}

Prior to World War II, the examination of military issues such as the use of force, intelligence methods, and alliances for security purposes, remained within the purview of the military, while scholars typically dedicated themselves to the study of military or diplomatic history. However, with the birth of the nuclear age and escalation of the cold war, nonmilitary professionals increasingly began to engage in the exploration of nuclear weapons as instruments of policy, the use of conventional forces, the balance of forces between nation states, and arms control. The growth of civilian involvement in security policy, necessitated the creation for university courses on the subject thus originating the academic discipline of Security Studies. ${ }^{1}$

As with most academic areas of expertise, over time Security Studies has evolved. Beginning in the 1990s and especially after the events of 9/11, there has been a call to redefine Security Studies as a field of study and while sometimes debatable and controversial, new themes emerged to include environmental and economic concerns which would lead to the subtopics of Environmental Security and Economic Security, in addition to Human Security, a new concentration which emphasized the demand to focus on the needs of the individual, including freedom from fear and freedom from want, as well as specific needs such as food security. ${ }^{2}$

Traditionally, the main focus of Security Studies has been national security or the protection of an individual nation from any internal or external threats or dangers and the measures taken to safeguard it. $^{3}$ But today in the new transnational world, Security Studies is invariably linked to International Security Studies, which covers issues of multilateral security concerns, rather than security matters and issues that pertain to a single country. ${ }^{4}$

US government information is mostly social science based, multidisciplinary, freely available on the World Wide Web and can be an extremely valuable resource for researchers in general and in particular for those in the Security Studies realm. However, US government documents remain relatively hidden to the people who they could most serve. These selected sources were assembled to assist the academic community and nonacademic specialists performing scholarly work in security studies, international studies, history, political science, sociology, criminology, and geography, new government information librarians, and librarians with assignments in the above areas who also have public service responsibilities (e.g., reference, research consultations, and instruction). 


\section{Databases}

Homeland Security Digital Library (HSDL), US

Department of Homeland Security (https://www

.hsdl.org/c/).

HSDL is a collection of digital documents related to security policy, strategy, and management from a variety of sources including federal, state and local governments; international governments and institutions; nonprofit organizations and private entities. It provides access to numerous US policy documents, presidential directives, and national strategy documents as well as specialized resources such as theses and research reports from various universities, organizations and local and state agencies. The Full Collection dates back to 2002 with some selected historical documents (e.g., legislation, executive orders etc.) going back even further, holds more than 182,000 documents, and has three browseable collections (Policy \& Strategy Documents, Special Collections, and Featured Topics) that provide links to selected subcategories. The search feature allows phrase searching using quotation marks, searching can be done by author, title, summary, publisher, or series and results can be refined by resource type or special collection, format, publisher, author, or language, and there is an advanced search option.

\section{MetaLib GPO, US Government Publishing Office (http://metalib.gpo.gov/).}

MetaLib is a meta-search engine that searches an assortment of electronic resources (catalogs, reference databases, digital repositories and subject-based web gateways) simultaneously, providing access to articles, reports and citations. Searches can be run using the Basic, Advanced or Expert modules.

Using the Basic search screen, one can search specific Government Publishing Office (GPO) databases (which equals the Catalog of Government Publications (CGP), govinfo, and GPO's bookstore) or General Resources (which includes USA.gov, PubMed, govinfo, Library of Congress, Access to Archival Databases (AAD), CGP, AULIndex of Military Periodicals, AGRICOLA Books, and EPA Publications and Newsletters).

The Advanced search allows searching by subject, title, author, ISSN, ISBN, and year. Boolean operators (AND, OR, WITHOUT) can be utilized, and quotes are used for phrase searching. Resources are organized by Quicksets (predefined groupings of up to ten resources); to reveal the databases behind a particular Quickset, click on its title and a list of databases will be provided. The previous and next tabs navigate through results and records/citations can be saved to a PC/E-shelf or emailed to a user. In particular, Quicksets such as Business + Economy, Environment, Heath + Safety and Agriculture provide information relating to Environmental Security, Economic Security and Human Security.

Within the Expert search, Basic or Advanced searches by Quicksets can still be performed but you have the additional option of searching by Agencies (a selected listing of Executive Branch Agencies' resources) and eliminating specific sources from a Quickset or Department resource list. One can also go a step further to create a customized Quickset by identifying the sources you want and click on its corresponding + button. The plus signs should have arrows to let you know that the information has been put on the clipboard, then go to My Resources under the My E-Shelf tab and your selections should be there. Save and name your resources. When you go to the Advanced search screen your newly created Quickset should be there.

\section{NCJRS Virtual Library and Abstracts Database, US Department of Justice (https://www.ncjrs.gov /Library.html).}

Maintained by the National Criminal Justice Reference Service (which was established in 1972 and funded by the US Department of Justice) the NCJRS Abstracts Database provides access to more than 225,000 records and more than 80,000 online resources in the NCJRS Virtual Library.

Historically, the NCJRS Virtual Library consisted of materials primarily focused on the subject area of criminal justice and its related fields of study. While its subject matter has remained the same, after October of 2014 the Virtual Library redefined its scope to only collect materials and resources produced, funded, and/or sponsored by the bureaus and offices of the US Department of Justice's Office of Justice Programs (OJP); effectively becoming an archive and repository for OJP information and resources. However, materials housed in the Virtual Library prior to October 2014 are still searchable in the Abstracts Database.

The NCJRS Abstracts Database presents bibliographic records and abstracts with links which supply full text access to selected pre-1995 and most post 1995 documents from the NCJRS Virtual Library. The Abstracts Database embodies the entire field of criminal justice, juvenile justice, and drug issues, with the exception of most legal decisions, opinions, and statutes. Subject areas include corrections, courts, crime prevention, criminology, drugs, juveniles, law enforcement, statistics, technology, and victims. Agency produced documents and final grant reports of OJP sponsored research are unique parts of the collection and many documents are from state and local governments, or international sources, as well as from books, journal articles, research reports and unpublished research. 
The Abstracts Database has three search types: "All" which find each term entered in the search box, "Any" which finds at least one of the terms entered in the search box, or "Phrase" which will find the exact terms entered in the search box in the exact order they are entered. General searching or searching by several fielded search options (Language, Title, Author, and Journal Name) can be done. Results can be limited by date and are displayed by relevancy but can be reordered by alphabetical title, NCJ (accession) document number and date. The Abstract Database also has an online thesaurus which allows users to search for materials located in the Abstracts Database using official NCJRS-controlled vocabulary. NCJRS may seem an oddity when thinking of security studies, but with titles such as A Comparative Study of Violent Extremism and Gangs; Human Trafficking Organizations and Facilitators: A Detailed Profile and Interviews with Convicted Traffickers in the United States; Responding to Transnational Organized CrimeSupporting Research, Improving Practice; and Examining the Structure, Organization, and Processes of the International Market for Stolen Data, it is clear this resources has its uses since it covers information on the topics of terrorism, transnational organized crime, human/drug trafficking and other national/ human security issues.

\section{Websites}

\section{National Consortium for the Study of Terrorism} and Responses to Terrorism (START) University of Maryland, College Park (http://www.start.umd.edu/). Established in 2005 with an initial \$12 million US Department of Homeland Security (DHS) grant, the National Consortium for the Study of Terrorism and Responses to Terrorism, better known as START, is a University of Maryland based research center committed to the scientific study of the causes and human consequences of terrorism in the United States and around the world. START supports research efforts of leading social scientists at more than fifty academic and research institutions, and is an Emeritus Center of Excellence in the US Department of Homeland Security's Science and Technology Directorate Office of University Programs' Centers of Excellence (COE) network, a university led consortia that works with the homeland security community to develop homeland security training and curricula and address homeland security challenges through inquiry.

START's website has collected, organized and made available a variety of resources that assist and promote research in terrorism. There is a listing of a diverse range of projects, conducted by START researchers and consortium members from around the world that fall under the categories of Terrorism and
Violent Extremism, Counterterrorism and Countering Violent Extremism, Risk Communication and Resilience, Radicalization and Deradicalization, and Unconventional Weapons and Technology; each listing gives the title and abstract of the project, the investigators and the project period (the time period when the project was conducted).

The Publication tab is a drop down menu that allows you to preselect a search option: All Publications, Academic Publications, START Publications or START Newsletters. Users can also search by Keyword in Title or Abstract with Publication Type, Research Area, Topics, Regions, Author(s), and Publication Date being limiters.

\section{Publications}

\section{National Defense University (NDU) Press, National Defense University (http://ndupress.ndu.edu/).}

The National Defense University Press publishes and disseminates vital and complex defense and national security scholarship in a variety of media to inform and influence defense and policy decision makers, as well as the joint professional military educational community and interested public. NDU Press issues books, occasional papers, case studies, policy briefs, strategic monographic, and the journal Joint Forces Quarterly (a joint military and security studies journal designed to inform and educate national security professionals on joint and integrated operations; government contributions to national security policy and strategy; homeland security; and developments in training and joint military education). Users can browse materials by their category or click on the publication tab to see all offerings and refine by publication type, region, or a wealth of topics such as but not limited to Deterrence, Homeland Security, Humanitarian Assistance \& Disaster Relief, Terrorism and Extremism, National Security Reform, Nuclear Policy and WMD Preparedness/Response.

\section{Strategic Studies Institute (SSI), US Army War College (https://ssi.armywarcollege.edu/pubs/).}

The Strategic Studies Institute, composed of civilian research professors, uniformed military officers, and professional support staff, supports the US Army War College curricula, provides direct analysis for Army and Department of Defense leadership, and publishes national security and strategic research and analysis which serves to influence policy debate and bridge the gap between military and academia. SSI produces three to five authored works or edited compilations per year: the Carlisle Papers-which report the findings of a major studentfaculty research initiative on a topic of strategic importance to the Army, the Department of Defense, and the larger 
community of strategic leaders; the Letort Papers-essays, retrospectives or speeches of interest to the defense academic community; Colloquium Reports, a report on the proceedings of larger conferences; Colloquium Briefs, two- to four-page briefs from a colloquia the Strategic Studies Institute has hosted or help funded; and the Key Strategic Issues List, compiled with input from the US Army War College faculty, the Army Staff, the Joint Staff, and other Army organizations to inform students, faculty, and external researchers of strategic topics requiring research and investigation.

However, the most popular SSI resource is the monographs; these policy-related reports provide recommendations, cover a variety of regional and strategic issues, and are very concise at usually under one hundred pages. They can be found by clicking on the SSI Publication link under the Pubs \& Analysis tab on SSI's website and then using the Categories limit to choose Monographs. Some recent titles are Professionalizing the Iraqi Army: US Engagement after the Islamic State; The Russian Military in Contemporary Perspective; Extremist Migration: A Foreign Jihadist Fighter Threat Assessment; and An Unnatural Partnership? The Future of US-India Strategic Cooperation. Older monographs going back to November 1992 (there is no December) can be discovered by using the drop-down menu to identify a particular month and year under the Archive section.

\section{Country Reports on Terrorism, US Department of State (https://www.state.gov/country-reports-on -terrorism-2/)}

United States law (22 U.S.C. $\$ 26566$ ) requires that the Department of State provide Congress a report on terrorism in regard to the countries and groups meeting criteria set forth in the legislation; this annual report is titled Country Reports on Terrorism. Beginning with the report for 2004, it replaced the previously published Patterns of Global Terrorism (2000-2003). There are both PDF and an electronic scrollable version of the report. Once you open the most recent electronic edition, on the right hand side of the screen is a drop-down menu that allows access to the reports of the years of the current presidential administration and a link to previous archived ones. The report begins with a foreword, and the first chapter is organized by geographic region with each country under its appropriate region. An overview is presented for all countries and information is divided into several sections, they are Terrorist Incidents; Legislation, Law Enforcement, and Border Security; Countering the Financing of Terrorism; Countering Violent Extremism; and International and Regional Cooperation. There are also additional chapters covering State Sponsored Terrorism; The Global Challenge of Chemical, Biological, Radiological, or Nuclear (CBRN) Terrorism; Terrorist Safe Havens; and Foreign Terrorist Organizations. The archived Country Reports on Terrorism has a left-hand navigation bar that allows one to choose the year, which brings up the report on the main screen and then the desired chapter can be selected.

Charmaine Henriques (chenriqu@iu.edu), Indiana University Bloomington

\section{References}

1. Brenda L. Horrigan, Theodore Karasik, and Rennison Lalgee, "Security Studies," in Encyclopedia of Violence, Peace, \& Conflict, 2nd ed., edited by Lester Kurtz, 18921900, vol. 3 (San Diego, CA: Academic Press, 2008), Gale Virtual Reference Library.

2. Daniel R. Snodderly, Peace Terms: Glossary of Terms for Conflict Management and Peacebuilding (Washington, DC: Academy for International Conflict Management and Peacebuilding, United States Institute of Peace, 2011), https://www.usip.org/sites/default/files/files/peace terms.pdf.

3. H. Victor Condé and Rita Cantos Cartwright, An Encyclopedia of Human Rights in the United States, 2nd ed. (Amenia, NY: Grey House, 2011), 164.

4. Cathal J. Nolan, The Greenwood Encyclopedia of International Relations, 4 vols. (Westport, CT: Greenwood, 2002). 